\title{
Economic Growth: Types and Factors
}

\author{
Mr. Aleksey Poliduts (Chelyabinsk State University, Russia) \\ Assoc. Prof. Dr. Yuner Kapkaev (Chelyabinsk State University, Russia)
}

\begin{abstract}
The article deals with the content of economic growth as an economic category through determining its type, indicators and factors. It proposed grading factors based on the various existing theoretical approaches. With all the variety of growth factors and options for sorting the basic separation occurs in the direct and indirect factors, internal and external, intensive and extensive, the factors of supply, demand and distribution, controlled and uncontrolled factors, factors of economic and non-economic, interchangeable and supplemented growth factors.

The author points out the main trends and features of economic growth, determining the pace and quality of economic growth in Russia at the present stage of development. The methodological basis of the study is the dialectical method of knowledge, which allows to study economic phenomena and processes in their constant interaction and development. Sources of data in the study is an analytical and statistical materials the IMF, the World Bank and the Federal State Statistics Service.

Formulate a set of restrictions for sustainable economic growth in Russia, due to the influence of various kinds of factors. As highlighted in its basic elements: the raw structure of Russian exports, weak competitiveness of downstream industries, the economic sanctions imposed in 2014 by the Western countries, reducing the purchasing power of the ruble against the reserve currencies. The results may help to improve the efficiency of stimulating the development and maintenance of high economic growth in the implementation of measures of state regulation both in Russia and in other countries.
\end{abstract}

\section{Introduction}

The conception of modern economic growth has been introduced into scientific circulation by the laureate of the Nobel Prize, American scientist Simon Kuznets, who noted the occurrence of this process in the end of 18th century. However, there is another point of view, and it is supported by the majority of modern researchers. They are sure that it started in 20 s of the 19 th century. From this position, obviously, we can consider economic growth originated in Europe as a response to the devastating Napoleonic Wars.

Modern economic growth is an incomplete process in its continuation which often changes the dominant trends. The current trends reflect such fundamental civilization changes that they, according to the opinion of scientists, can lead to the emergence of a fundamentally new society.

Economic growth is characterized by direction, social necessity, and also by government regulation.

Scientific sources offer different definitions of "economic growth" category, a lot of them claim to be a complete reflection of its essence. It is necessary to show two main points: firstly, such conceptions as "economic growth" and "economic development" should be distinguished, and secondly, in a variety of definitions of growth, as a rule, one or another essential characteristic of that category is reflected.

According to J. Tinbergen, economic development and economic growth "are compatible with each other, but not identical" (Tinbergen, 1980). An important feature of the development is in improving the welfare of all groups of the population, so that its financial security increases. But economic growth does not mean the equal financial security improvement of all groups of population.

The economic development of society is a controversial and difficult in measurement process, also it is characterized by irregular flow, structural shifts in economy, improvement of conditions and increase of life quality of the population. Differentiation between the concepts of "economic growth" and "economic development" was introduced in economics by the American economist Joseph Schumpeter: "You can place in a row as many mail coaches as you wish, but you will not receive the railway by this" (Schumpeter, 2001). The reason is that the essence of economic growth is in increase production and consumption of the same goods and services, in this example, mail coaches. Economic development is, mainly, in creating something new, unknown previously, in our case, the railways. Economic development involves both the emergence of some new (or in a new quality) benefit and implementation of new production methods, development of new markets, receiving new sources of raw materials, appropriate restructuring and so on.

\section{Methodology and Results}

Different interpretations of the "economic growth" concept provide both quantitative and qualitative characteristics. Quantitative characteristic shows us changes in the amount of produced goods and services, reflects the dynamics of these changes; qualitative characteristic points to the possibilities of economic system in meeting the new growing needs of society. Due to the fact that it is non-static, moving and changing process, it has always a numerical index for a certain date. Economic growth is characterized by the dynamics of such 
absolute macroeconomic indicators as gross domestic product (GDP), gross national product (GNP), national income, and others. The relative indicators of economic growth which characterize it from the quantitative side are the value of GDP per capita, disposable income of the population per capita, and also attributable to per capita indicators of consumption, savings and investments. The rates of industrial production growth in whole and for the main sectors and types of products, indicators of economic efficiency, for example, labor productivity, are also being considered.

Economic growth is reflected by the positive dynamics of the considered indicators. Considering recent trends, the world practice offers to view the rates of $4 \%$ per year as "favorable" economic growth. The rates of growth more than 4\%, which India and China display, for example, are considered to be forced, and they are connected with the activities for the withdrawal of the country's economy from the crisis or emergency escalating of economic potential. For example, GDP dynamics of Russia this year went into the negative plane and by the end of 2015 it is projected to decline by $2.8 \%$. According to the estimation of the Ministry of Economic Development, Russian economy can return to positive growth of $2.3 \%$ already in 2016 .

The qualitative aspect of economic growth is determined by living standards and quality of life indicators. The living standard is estimated by consumer basket, cost of living, GDP structure by use; level of services development (the number of doctors per 10 thousand people, the number of hospital beds per 1 thousand people, etc.); state of the labor forces (average life expectancy, level of education, share of education expenditure in GDP, etc.), and others. The quality of life is reflected by the content of labor and leisure activities, level of labor and life comfort, environment, functioning of social institutions, etc.

The most completely features of the process of economic growth are expressed in its type. Several key points of view on the types of economic growth are distinguished in economic literature. The first point of view gives us an idea of the types of economic growth from the perspective of quantitative or qualitative changes in the factors of production, the so-called factorial approach. There are two types of economic growth allocated in economic theory - intensive and extensive, in addition, as a part of an intensive, there is an innovative type of economic growth. Extensive type of growth is characterized by quantitative increase of use of one or more factors of production. Accordingly, there are capital, labor and resource subtypes of extensive economic growth. When there is a qualitative improvement in the factors of production, such as use of ultra-precise modern equipment in goods production, cost-effective non-waste technologies and more skilled workforce, we can talk about the intensive, or qualitative, type of economic growth. Here it must be said that these two types of growth are interrelated, they should not be contraposed to each other.

The second point of view is determined by the needs and possibilities of the society, and also by the rates of population growth. The essence of this approach is contained in the works of British scientist and economist Roy Harrod, who introduced the concept of natural, guaranteed and actual types of economic growth. Natural economic growth is caused primarily by population growth, increase in the needs of this population, and also by desire of every individual to satisfy their material and spiritual needs as fully as possible, while using all potential opportunities for economic growth. R. Harrod defines guaranteed economic growth as some predicted line of development, «...on which the entrepreneurs are disposed and are satisfied with what they are doing. Actual growth is the real level of economic growth as a result of the combined action of natural and guaranteed economic growth» (Harrod, 1959).

The third point of view considers the economic growth from the perspective that it is determined by productive forces, equipment and production technologies. In this context, economists distinguish pre-industrial (traditional society stage), industrial and post-industrial types of economic growth. Pre-industrial type of growth takes place in those national economies where the main industry is agriculture and its part in GDP exceeds $50 \%$. In developed capitalist countries pre-industrial stage of agricultural development was finished in the 19th century, while some of the economically backward countries are being in it today. Pre-industrial type of economic growth is characterized, as a rule, by very low rates of economic growth. Industrial type of growth is characterized by overturn in the material basis of production, as a result the industry follows the agriculture and begins to play a decisive role across the national economy. Historically, industrial growth in modern developed countries has started at the beginning of 19th century and it is still going on. It brought both significant quantitative and qualitative changes in the national economies of these countries. As none of the economies at the present stage of development yet belong to the post-industrial type of economic growth and there are only preconditions for postindustrial economic society, scientists such as E. Pestel, suggest that the central place in the economy will again take the man and his life quality, but at a higher level compared to traditional society. «High level of industry will provide also a high level of social welfare in whole, new needs and requirements will be met relatively quickly. Dangerous technologies will be curtailed, and the environment will be maintained in proper condition» (Pestel, 1988).

By the level of economic criminalization there are distinguished legal and shadow types of economic growth. Both of them are inherent to immature economic systems, and they usually exist in them in parallel. Shadow growth is the result of functioning of the so-called shadow economy segment, in which management, business and resources use acquire a distorted form and develop outside the legal field. According to various estimates, 
the volume of the shadow segment in Russian economy varies from 20 to 50\% of GDP. The Security Council's report says that the informal segment of national economy involves about 10 million people, and the largest part of its turnover is generated by service sector. For comparison, the same indicator in Japanese economy is only $4.5 \%$ of GDP (Savchenko, 2005).

From the position of national economic interaction with the world economy there are distinguished importsubstitution and export-oriented types of economic growth. These types of growth show how differently external factors influence on the national economy and determine the level of that influence. However, they are purely theoretical because they do not occur in pure form. As a rule, while one determines the type of growth in a particular country, he can observe the features inherent to several types of economic growth.

Identification of factors takes a key position in the process of economic growth research. Factors of economic growth are the foundation of the growth process, which determines the level and dynamics of change, directly affects the magnitude of increase in real output, increases its efficiency, causes different types of growth. Economic theory defines the factors of economic growth as the processes and facts that determine the ability to increase real output, thus improve the efficiency and quality of growth.

It is obvious that the main drivers of economic growth for both developed and developing countries are the same, which are labor and reproductive factors. These factors have predominantly reproductive nature, and they are capital, territory, labor, scientific and technological progress, innovation and productivity, efficiency of productive unit, and so on. The factors both can directly and indirectly, positively and negatively effect on the rates and quality of growth. There is an important clarification: as a rule, economy in a given time and place is influenced not by all known and existing growth factors, but only by their definite set. Therefore, we analyze the sampling from the main factors that largely determine economic growth.

Economic literature mostly offers us the following gradation of growth factors: direct and indirect, extensive and intensive; factors of supply, demand and distribution; controllable and uncontrollable; substituted and complemented; economic and non-economic. Such a variety of factor sorting can be attributed to the difference in views of researchers in relation to the problems of economic growth.

For example, V. D. Kamaev has identified the following groups of growth factors: general, or permanent, and special, or momentary, and also controllable and uncontrollable. The degree of controllability by factors of economic growth in short and long terms shows the real capacity of the economy to achieve adjusted growth rates. For example, such factors as demographic situation, internal migration, energy intensity of production, social differentiation and some others due to objective reasons possess limited controllability in short and medium terms. Controllable factors which, if necessary, are relatively easy to control, include such factors as inflation, natural monopolies rates, level of taxation, government costs, fixed capital investments, money supply (Kamaev, 2001).

American scientists K. R. McConnell and S. L. Brue offered to distinguish the factors of supply, demand and use, or distribution, by functional features. Supply factors are quantity and quality of natural and human resources, fixed capital, level of scientific and technological progress and technologies, level of prices of productive resources, credits availability and so on. Demand factors are consumer expenses, investment and state costs, increased export, etc. Factors of distribution can include the order of income distribution between business entities, distribution of productive resources between industries, businesses and regions.

Roy Harrod distinguished from the variety of factors international, state and industry factors; scientific, technical and resource factors; structural, organizational and administrative factors; extensive and intensive factors; material and non-material factors; economical, political, social factors; subjective and objective factors.

Some researchers segregate economic and non-economic factors of growth. Non-economic factors of economic growth include military-political, geographical, climatic, demographic, social, cultural and other conditions.

Robert J. Barro and J. Sala-i-Martin examined 62 factors of economic growth and segregated 25 of them increasingly affecting it. They are GDP of initial period, investment, share of raw materials in exports, share of extractive industry in GDP, openness of economy, distortion of the exchange rate, share of primary education, profitability of shadow economy segment, expected duration of life, confessional structure of population and others.

According to the IMF experts' analytical review there are such positively correlated with economic growth factors as share of investment in GDP, primary education coverage, health indicators, openness of the global economy, share of non-primary goods in export.

According to position of the Russian Federation's Government, economic growth is one of the main strategic purposes of the national economy. It is reflected in the "Main activities of the Government of the Russian Federation for the Period up to 2018", in the Decrees of the President of the Russian Federation from May 7 , 2012 No 596 - 606, in the Concept of Long-term Socio-Economic Development of the Russian Federation for the Period up to 2020, in the Annual Presidential Addresses. These documents declare the following long-term 
priority of modern Russian society development - the creation of a socially-oriented innovative type system by achieving the sustained economic growth in the long term as the strategic purpose.

The previous six-year period can be characterized by global economic and financial crisis of 2008-2009 and by the subsequent restoration. Due to the high dependence on the sector of energy resources, the accumulated imbalances and disparities, the economy of Russia was exposed to the crisis factors more than the economies of other countries. In 2014, economic growth has slowed down, GDP growth, according to the Federal State Statistics Service, was only $0.6 \%$, inflation dynamics and the growth of the budget deficit sharply accelerated. It was caused by growth-constraining factors.

Firstly a serious decline in prices for traditional resource commodities should be mentioned. Thus, prices for industrial metals began active reduction in 2011 - 2012, natural gas price - in 2012 - 2013, and oil prices - in the second half of 2014. According to experts, these changes on the resource commodities market are long-term, and reduction in the price level leads to attenuation of Russia's payments balance and reduction of budget revenue.

The second growth-constraining factor is geopolitical escalation, it increased economic and political uncertainty and closed debt financing in foreign markets and modern technology inflow for many national companies.

The third factor is reduction of the working-age population in spite of the general stabilization of the demographic situation. The reason is in birth reduction in the 90 -ies of the last century. Annually the workingage population is reduced by approximately 1 million people, and this fact seriously restricts potential growth rates of the economy and increases the burden on the pension system.

In addition to these factors, there are some accumulated structural problems in economy like the imbalances of economic development (reduction of investment share in GDP, growth of economic dependence from instable oil and gas income, decline of quality and quantity indicators of the budgetary system costs), the high share of state presence in economy with low efficiency of its participation in it, the necessity of improving the efficiency of state costs, the gap from the world rates of technological development. It is necessary to form a new technological base of long-term growth, increase the costs in such high-tech areas as nanotechnology and information technology, pharmaceutics and biotechnology, microelectronics, engineering systems, nanophotonics, innovative technology in education and health. At the state level it is also important to help in increase and diversification of export, to reduce the share of consumer goods and services in total import, to evolve competition in domestic markets, to improve investment and business attractiveness of the Russian economy. As the main reason why investors and investment funds aimed at implementation of long-term projects restrict their activity, experts and businessmen designate political risks which, in their opinion, significantly increased in recent years in Russia. The results of opinion poll of 50 top executives of large foreign companies and funds point to the fact that corruption, rule of law and respect for property rights are still ignored in Russia.

Formation of a new growth model is also based on the need for "bottlenecks relieve", we should develop transport and energy infrastructure using pension funds and other extra-budgetary sources of long-term investment resources, create conditions and attract private investment to development projects of transport networks and energy, housing and engineering infrastructure.

\section{Conclusion}

Today the problems of sustainable economic growth achievement are important for all countries of the world, either developing or developed. This is largely due to population growth and resource exhaustion, economic shocks. Appreciation of resources, in turn, leads to decrease in production profitability. On the other hand, industrialization, growth of industrial production and technological progress leading to economic growth negatively impact the environment, pollute air, soil and water, that is harmful to population health.

The growth in GDP and national wealth does not imply equitable distribution of wealth among the population, because many factors affecting economic growth, such as the means of production and capital, are privately owned. Existing high income differentiation of society does not solve the problem of poverty. In this context, the aim of society is not only economic growth, its aim is sustainable economic development, which increases the level and quality of life, reduces the share of food expenses and income inequality in society.

\section{References}

- Barhatov, Kapkaev, Pletnev, 2004. The Development and Economic Growth in the Region. The South Urals State University's Publishing House, Chelyabinsk.

- Barhatov, Zhuravleva, Gorshkov, 2007. The Economic Theory: textbook. Finance and Statistics, Moscow.

- Barro, Sala-i-Martin, 2014. The Economic Growth. BINOM. The Knowledge Laboratory, Moscow.

- Bethell, 2008. The Property and Prosperity. IRISEN, Moscow. 
- $\quad$ Blaug, 2009. «Kuznets, Simon. Great Economists since Keynes: An introduction to the lifes \& works of one hundred great economists of the past», Library of "Economic School", 42, p. 131-134.

- Denison, 1975. The Evaluation of Sources of Economic Growth as the Basis of Long-time Forecasts, in the book Long-time planning and forecasting. Progress, Moscow.

- Harrod, 1959. Towards a Dynamic Economics. Some Recent Developments of Economic Theory and Their Application to Policy. Foreign Literature Publishing House, Moscow.

- Kamaev, 2001. The Economic Theory. VLADOS, Moscow.

- Keynes, 2007. The General Theory of Employment, Interest and Money. Selected. Eksmo, Moscow.

- Kuznetsova, 2001. The Economic Growth: History and Modernity: Textbook. University Book, Moscow.

- Lucas, 2013. Lectures on Economic Growth. Publishing House of the Gaidar Institute, Moscow.

- Mau, 2003. «The Economic Growth and Post-industrial Challenges», Problems of the Theory and Practice of Forecasting, 1, p. 32.

- McConnell, Brue, 1997. The Economics: Principles, Problems and Policies. Volume 1. Moscow.

- Pestel, 1988. Beyond the Limits to Growth. Progress, Moscow.

- Sachs, 1996. Macroeconomics. The Global Approach. Delo, Moscow.

- Savchenko, 2005. «The Exogenous Factors of Sustainable Economic Growth in Russia: the scientific research». The Kuban State University, p. 197.

- Schumpeter, 2001. The History of Economic Analysis: In 3 vol. Economic School, Moscow.

- Sharaev, 2006. The Theory of the Economic Growth. GU-VESh, Moscow.

- Spence, 2013. The Next Convergence: the Future of Economic Growth in a Multispeed World. Publishing House of the Gaidar Institute, Moscow.

- Solow, 2002. Growth Theory. Companion to Contemporary Economic Thought. The School of Economics, Moscow.

- Tarakanov, 2008. «The Factors of Economic Growth Accelerating: a Comparative Analysis: the scientific research». The Institute of World Economy and International Relations RAS, p. 202.

- Tarasevich, Grebennikov, Leussky, 2006. Macroeconomics: A Textbook. High Education, Moscow.

- $\quad$ "The Main Activities of the Government of the Russian Federation for the Period till 2018" // the Text of a Legal Act

- Tinbergen, 1980. The Review of the International Order. Progress, Moscow.

- Uskova, Lukin, Vorontsova, Smirnova, 2013. The Problems of Economic Growth in the Territory. ISERT Russian Academy of Sciences, Vologda.

- Voronin, 2004. Russia: The Economic Growth. Financial Control, Moscow. 